\title{
Towards a Generic Model of Human Resource Management
}

\author{
H.H.D.N.P. Opatha ${ }^{1}$ \\ ${ }^{1}$ Senior Professor and Chair of Human Resource Management, Department of Human Resource Management, \\ Faculty of Management Studies and Commerce, University of Sri Jayewardenepura, Sri Lanka \\ Correspondence: H.H.D.N.P. Opatha, Department of Human Resource Management, Faculty of Management \\ Studies and Commerce, University of Sri Jayewardenepura, Sri Lanka.
}

\author{
Received: May 27, 2021 \\ doi:10.5539/ibr.v14n7p58 \\ Accepted: June 15, $2021 \quad$ Online Published: June 16, 2021 \\ URL: https://doi.org/10.5539/ibr.v14n7p58
}

\begin{abstract}
This theoretical basic research paper was written in order to accomplish three research objectives: (1) to perform a brief description of selected popular models of Human Resource Management (HRM) developed by various scholars or authors; (2) to revisit and review the model of HRM developed by me in 2009; and (3) to introduce a generic model of HRM with an adequate theoretical base. It revealed that at least five popular models exist in the literature of HRM and they were briefly reviewed. The relevant review done with regard to the model developed locally as the first model of HRM in 2009 revealed that it is an internally focused but comprehensive and distinct model with a necessity of incorporating forces which exist in internal and external environments. Finally, a generic model of HRM which is composed of seven interrelated components such as internal environment, external environment, HRM fields and functions, HRM outcomes, organizational outcomes, HRM academic and professional factor, and feedback through evaluation was developed and presented by using several common theories, perspectives, arguments and logical beliefs. Hopefully the generic model will be a significant value addition to the existing local as well as international body of knowledge of HRM which is a highly recognized academic discipline and an established practice.
\end{abstract}

Keywords: human resource management, HRM model, generic model

\section{Introduction}

I (the author of this paper) originated a simple but distinct definition of HRM in 2009 (first it was published in 1995 in Singhala language) and it is: "HRM is the effective and efficient utilization of human resources to achieve goals of an organization". Viewing from 12 definitions given by various authors 10 common characteristics of HRM were identified and they are: (1) HRM fucuses on managing people; (2) it is managing people at work or employees who make up an organization; (3) it exists within an organization; (4) it generally attempts to serve for the organization where it is practiced, employees working for it and society at large; (5) it is the human side of Business Administration; (6) it is a traditional functional field of Business Administration;

(7) it was traditionally termed as Personnel or Personnel Management; (8) it has a set of activities that focuses on effective use of employees for the accomplishment of organizational goals; (9) it is mainly concerned with human relationships within an organization; and (10) it has policies, practices and systems influencing employees (Opatha, 2009).

HRM is a recognized academic discipline as well as a recognized profession in Sri Lanka and in the world too. It provides many solutions to create and enhance success and progress of success of organizations; and it is the field that is concerned with improving the standards of living of people at work (Opatha, 2019 ${ }^{1}$ ). Opatha (2009) presents five reasons of why HRM is of very importance for an organization. They are: (1) Human resources are the most important resource that managers utilize to achieve goals of an organization; (2) Quality of other functional fields of management heavily depends on quality of HRM in an organization; (3) HRM is a vital responsibility of every manager in an organization; (3) HRM contributes to organizational success and then societal success; and (5) Management of employees is more difficult than managing other resources. A comprehensive study based on a content analysis of 30 textbooks with regard to the case for teaching HRM in management education done by Opatha $\left(2019^{2}\right)$ revealed 13 common reasons which underline how much HRM is important to us. These thirteen common reasons in the order of importance are: (1) Organizational success; (2) Sustainable competitive advantage and organizational improvement; (3) Every manager's vital responsibility and contribution to societal success (two reasons); (4) Enhancing professional life success; (5) Enhancing personal 
life success; (6) Enhancing quality of organizational life for employees, uniqueness of human resources, and contribution to the natural environment (three reasons); (7) organizational survival, other functional field dependency, and legal compliance (three reasons); and (8) HRM profession's growth.

It is true that there is no generally accepted model of HRM in the literature which can be taught to students of HRM and which can be applied by HRM professionals in industries in Sri Lanka and perhaps in the developing context. The increased understanding of modeling HRM in detail acquired by the lecturer will lead to increase his or her structuring dimension of lecturing behaviour, which has a significant positive impact on student satisfaction of learning (Opatha, 2020). My observations of HRM teachings performed by academics and professionals in Sri Lanka uncover that different models, particularly foreign ones are being utilized by some academics and professionals and of course no models of HRM which represent an overview of HRM are being utilized by others. A careful examination of the textbooks on HRM reveals that there are some textbooks which do not present a model of HRM and a certain number of books do present. There is a need of developing a model of HRM which is a relatively more comprehensive, richer, understandable, and teachable one that will be more useful for HRM academics and professionals, at least in Sri Lanka and in the developing context. Also, I have a personal scholastic need and a social obligation to develop and present such a model to the readers of this paper and particularly to my students to enhance their learning of HRM by being the first Professor in HRM in Sri Lanka and the first Senior Professor of HRM (Chair) in Sri Lanka.

I established three objectives for writing this theoretical research paper. They are:

1. To perform a brief description of selected popular models of HRM developed by various scholars or authors.

2. To revisit and review the model of HRM developed by me in 2009 .

3. To introduce a generic model of HRM with an adequate theoretical base.

\section{Method}

This research paper is non-traditional by being descriptive and prescriptive. This research paper is theoretical as it is based on the ideas and perceptions. Indeed, this is a research study done by using two non-scientific methods such as authority mainly and intuition to a certain extent. Authority is a non-scientific method of acquiring knowledge and it involves seeking answers from authority or experts on a specific subject (Davis \& Cosenza, 1985; Nazario-Romero, 2016). As this research paper aims at forming an essential foundation for modeling the subject of HRM by making an original theoretical contribution to the existing body of knowledge of HRM, it is considered as a basic study. In order to achieve the first objective, a relevant literature survey was done by using the desk research strategy. Textbooks and scholar books on HRM published by relevant authorities were utilized. The available textbooks and scholar books were first examined for exploring the availability of models of HRM. Not all but only some textbooks and scholar books had models and only five models of HRM were selected for the purpose of reviewing because of their popularity and lucidness. My writing with regard to the model was used for achieving the second objective of the paper. Arguments and strengths from the selected models, my logical beliefs, and some generally accepted relevant theories and perspectives were utilized in order to achieve the third objective which leads to the major contribution of this paper.

\section{Popular Models of HRM}

I define a model of HRM as a framework that theoretically describes and explains how a system of HRM works. It is instrumental for understanding how various components or elements of HRM interrelate, depend on each other and work to produce certain results. Here a model of HRM means a framework that presents an overview of HRM.

The Matching Model by Devanna, Fombrun \& Tichy is a popular model of HRM and it was developed in 1984 by Devanna, Fombrun, \& Tichy who were academics at the Michigan Business School, USA. An alternative name for this model is the Michigan Model of HRM. The model presents four components which include: (1) Mission and Strategy: Mission is the reason for being of an organization. Strategy includes both the process by which the objectives of the organization are chosen from the set of all feasible objectives that are available to the organization and the process by which organizational resources are used to carry out those objectives; (2) Organization Structure: This means the way of designing the organization to carry out works to achieve organizational objectives including division of labour, job designing, departmentation, delegating authority etc.; (3) HRM: This means systems of recruiting and developing people to do jobs defined by the organization's formal structure, and evaluating people's performance and rewarding it; and (4) Environmental Pressures: These include economic forces, political forces, and cultural forces which have effects on the above mentioned three components. 
The model stresses that HRM is an integral part of Strategic Management (SM) which consists of mission and strategy, organization structure, and HRM. The model points out that HRM is affected by mission and strategy and organization structure and also HRM does affect mission and strategy and organization structure, implying that the four components are interrelated and inter-depended. A major point or idea given by the model is that HRM plays a critical role in strategy formulation and implementation being an integral part of SM. Another major point is that HRM needs to be matched with mission and strategy and organization structure. There are environment pressures which affect SM including HRM. This point can be considered as the third point deriving from the model. The model is a general model showing the linkage between SM and HRM, and however, it does not indicate certain specific functions of HRM.

The Harvard Model of HRM by Beer, Spector, Lawrence, Mills, \& Walton is another popular model of HRM. This model was developed by Beer, Spector, Lawrence, Mills, \& Walton being academics at the Harvard University in 1984; and this model is alternatively called the map of the HRM territory (Beardwell \& Claydon, 2007). The model presents five components which include stakeholder interests, situational factors, HRM policy choices, Human Resource (HR) outcomes, and long-term consequences. These five components are interrelated in a larger system and in the model, there is feedback that means that long-term consequences impact stakeholder interests and situational factors. An example is that increased profit which is a measure of organizational effectiveness impacts shareholders in the way that increases their satisfaction. HRM policy choices include employee influence (industrial relations and employee involvement); human resource flow (employee resourcing and HR development); reward systems (reward management); and work systems (motivation, control and work systems) (Vickerstaff, 1992). According to the model, there are stakeholders and situational factors which affect HRM policy choices, which subsequently result in HR outcomes, which ultimately lead to long-term consequences.

Major ideas of the model are: (1) When HRM policy choices are made stakeholder interests are to be taken into consideration; (2) There is a need of locating HR policies in a wider environmental context that is having external forces and internal forces; (3) HRM activities generate two types of results, i.e., HR outcomes and long-term outcomes; and (4) HRM is for well-being of employees, success of the organization, and well-being of the society. The labelling of the components of HRM policy choices may not be consistent with traditional labelling of HRM functions. Job satisfaction, job involvement, lack of counter-productive behaviour, attendance can be considered as important HR outcomes though they have not been included specifically in the model.

The Model of HRM by David Guest is a well-known model of HRM, and David Guest from London School of Economics developed this model of HRM in 1987. According to his thinking and proposing HRM comprises a set of policies designed to maximize organizational integration, employee commitment, flexibility and quality of work, and within this model, collective industrial relations have only a minor role (Guest, 1987). This model can be viewed as a theory of HRM (Legge, 1995) and it theorizes that policies lead to HR outcomes (which are strategic planning/implementation, commitment, flexibility/adaptability, and quality) then lead to organizational outcomes (which include high job performance, high problem-solving, successful change, low turnover, low absence, low grievance level, and high cost-effectiveness). In the model basically HR policies represent HRM functions, and Guest (1987) identified HR outcomes as goals of HRM.

The Guest model of HRM is a significant contribution to understand and explain a particular approach to managing people at work. Some of the major points of the model are (adapting from Guest, 1987): (1) HRM activities (so called policies) need to be designed and implemented in order to achieve four goals such as integration, commitment, flexibility, and quality; (2) The achievement of the four goals will lead to organizational outcomes, i.e. high job performance, high problem-solving, successful change, low turnover etc.; (3) If HR policies can be integrated into strategic plans, if they cohere, if line managers show the importance of HR cognitively and behaviourally, if there is an identify of interest (what is good for the organization is perceived by its employees too as good for them), organizational strategic plans get implemented successfully. The model does not directly consider some organizational outcomes such as profits, market share, legal compliance, and customer service quality. Ethicality of employees as a goal of HRM seems to have not been considered.

Jackson and Schuler presented a framework for managing HR through strategic partnerships in 2003. The Framework for Managing Human Resources through Strategic Partnerships by Jackson \& Schuler is considered by me here as an important model of HRM even though most of the general textbooks on HRM do not have a discussion on it. A major reason for such a non-discussion is more likely that the model was developed as a unique one exclusively for the relevant textbook. According to the authors HRM refers to all of the activities that an organization uses to affect the behaviours of all the people who work for it; and because the behaviours of 
employees influence profitability, customer satisfaction, and a variety of other important measures of organizational effectiveness, managing HR is a key strategic challenge. The framework presents a discussion of what an organization needs to consider in managing HR effectively. I believe that this framework is comprehensive and very useful. It has five components, i.e., stakeholder satisfaction, HRM activities, organizational environment, global environment, and the HR profession. All the five components have effects on each other. Most importantly the framework stresses that HRM does not occur in a vacuum but it occurs in a larger context internally, locally, and multi-nationally.

Managing HR through strategic partnerships means performing HRM activities in the way that makes stakeholders, particularly key ones satisfied. Jackson \& Schuler (2003), by presenting the framework, define success as effectively serving the interests of primary stakeholders, and theorize that their interests define an organization's fundamental objectives which, in turn, drive its approaches to managing employees.

The HR profession is a special component in this model of HRM which has not been seen in other models. According to Jackson \& Schuler (2003) understanding the HR profession is essential for successful managing HR in an organization as it provides HR professionals who have the right expertise (knowledge and skills) to design and implement HRM systems without which managing HR does not become effective. Some major points of the model are (adapting from Jackson \& Schuler, 2003): (1) HRM activities can be formal policies and daily practices. Formal policies represent statements of expectations and aspirations; (2) HRM activities do not occur in a vacuum and they are shaped by various internal forces, which, in turn, get shaped by forces in the external global environment; (3) Change is an ongoing process in the organization and HRM activities play a central role in supporting the organization's ongoing process of change; (4) It is a must that line managers in all fields of organizational management get involved in HRM; and (5) Professional HRM expertise is essential for the design and implementation of effective HRM systems. The model does not consider HRM academics as a separate factor or along with the HR profession. HRM academics indeed have a positive impact on originating new concerns for HRM and formulating solutions for various HRM issues being faced by a particular organization or organizations in industries in general.

The ARDM Model of HRM by Ivancevich is the next model of HRM presented here. Ivancevich (2010) introduced this model called the ARDM model for HRM. The ARDM $(\mathrm{A}=$ acquiring, $\mathrm{R}=$ rewarding, $\mathrm{D}=$ developing, and $\mathrm{M}=$ maintaining and protecting) $\mathrm{HRM}$ model presents four major components, i.e., external environmental influences, internal environmental influences, human resource processes, and desirable end results, and explain the interrelationships among them. The model emphasizes some of the major external and internal environmental influences that directly or indirectly affect the match between HRM activities and people (Ivancevich, 2010). It is a mention in the model that it is not possible to include every important environmental influence, HRM activity, or criterion for effectiveness, and instead, the model provides an orderly and manageable picture of what HRM activities (HRM functions were labelled as HRM activities) intend to accomplish. It is possible to see four words (in fact four verbs) such as 'Diagnose, Prescribe, Implement, and Evaluate' in the model. When an employee problem (example: an employee is not properly performing his or her job) occurs, that needs to be solved. In solving the HR problem, the HR manager is required to diagnose the problem (to identify its cause or causes), then prescribe (to make a solution), then implement (the made solution is activated), and finally evaluate (to assess the effectiveness of the made solution in solving the problem). Hence, the ARDM model can be applied by the manager to making decisions.

Major points of the model are: (1) There are four main HR processes, i.e. acquiring HR, rewarding HR, developing HR, and maintaining and protecting HR; (2) Focus of each of these four major HR processes is on people and results; (3) HR activities have to be designed and implemented in the way that they lead to desirable end results (socially responsible and ethical practices, competitive high quality product/s, competitive high quality service/s); and (4) A set of relevant factors needs to be focused in HRM. The model does not provide specific HRM functions though it presents four major areas of HRM.

\section{Revisiting the Model of HRM by Opatha}

Opatha, the author of this research paper, presented an original model in 1995 in his book titled SEWAMANDALA KALAMANAKARANAYA (Personnel Management) in Singhala medium. Later I published the same with few additions in the book titled Human Resource Management: Personnel in 2009. Refer to Figure 1. This is the model of HRM developed by me as an endeavour to pioneer Sri Lankan literature of HRM. As a matter of fact, this is the first model of HRM developed in Sri Lanka. The model consists of four components, i.e., HRM functions, objectives, strategic goals, and generic purpose. I used the term 'function' for the term 'activity', hence HRM activities (labelled by other authors) were labelled as HRM functions. The model presents 
a comprehensive list of HRM functions starting with job design and ending with labour relations. Altogether, eighteen HRM functions exist in the model. These functions are interrelated (from the arrows shown in Figure 1 this is visible) and some functions (example: successful performance of selection function depends on successful performance of recruitment function) are interdependent.

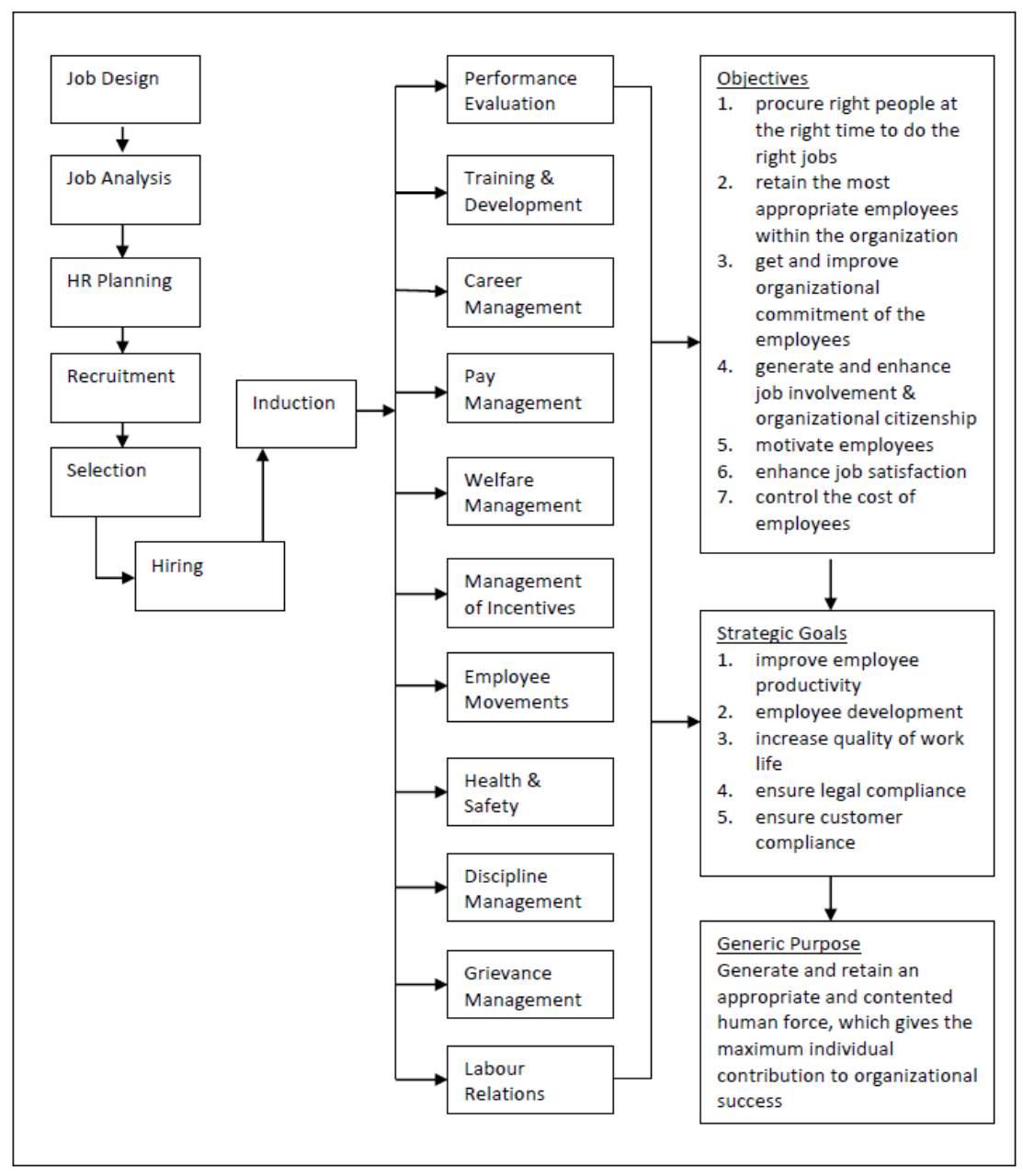

Figure 1. Opatha's Model of HRM

Source: Opatha (1995); Opatha (2009)

Opatha (2009) theorizes that generic purpose of HRM, i.e., to generate and retain an appropriate and contented human force, which gives the maximum individual contribution to organizational success, needs to be accomplished by achieving strategic goals of HRM and objectives of HRM, and in order to achieve them, a series of functions called HRM functions is to be performed. Managing people at work in an organization consists of 18 functions called HRM functions which need to be performed in order to achieve objectives of HRM, and then goals of HRM. Accomplishment of objectives and goals of HRM will finally result in realizing the generic purpose of HRM which is in simple "to generate and retain right employees who give maximum contributions to achieve organizational success".

The model presents four major points which are: (1) A sequential process exists from job design to induction. It implies that job design has to be done first and then job analysis and then human resource planning and so on; (2) In respect of functions from performance evaluation to labour relations, usually a sequential process does not exist. It implies that these functions can be performed simultaneously or there are no pre-requisites or post-requisites; and (3) HRM functions contribute to achieve objectives of HRM and strategic goals of HRM; and (4) Achievement of objectives and strategic goals of HRM leads to achieve generic purpose of HRM.

I consider this model as comprehensive, and indeed it is an internally focused model meaning that it does not include environmental aspects, both external and internal. In reality there are forces which exist in the business 
environment and they influence and moderate the way of managing employees in an organization. For example, a demand from a group of people that comes to the organization to stop environmental pollution caused by the organizational work influences the relevant management to start and implement seriously a program that makes the employees of the organization green. I consider this model as useful owing to the four major points which were mentioned in the above paragraph. My experience of using this model for teaching HRM to thousands of undergraduate and postgraduate students was highly positive. By the time of writing this paper I possess 34 years of active teaching experience.

\section{A Generic Model of HRM}

I hereby introduce an advanced model of HRM for which I call Generic Model of HRM. This model takes into consideration of many dynamics of managing people at work in an organization. Though the model can be considered as an advanced model I present it here in the way that is simple and distinct as well. Refer to Figure 2.

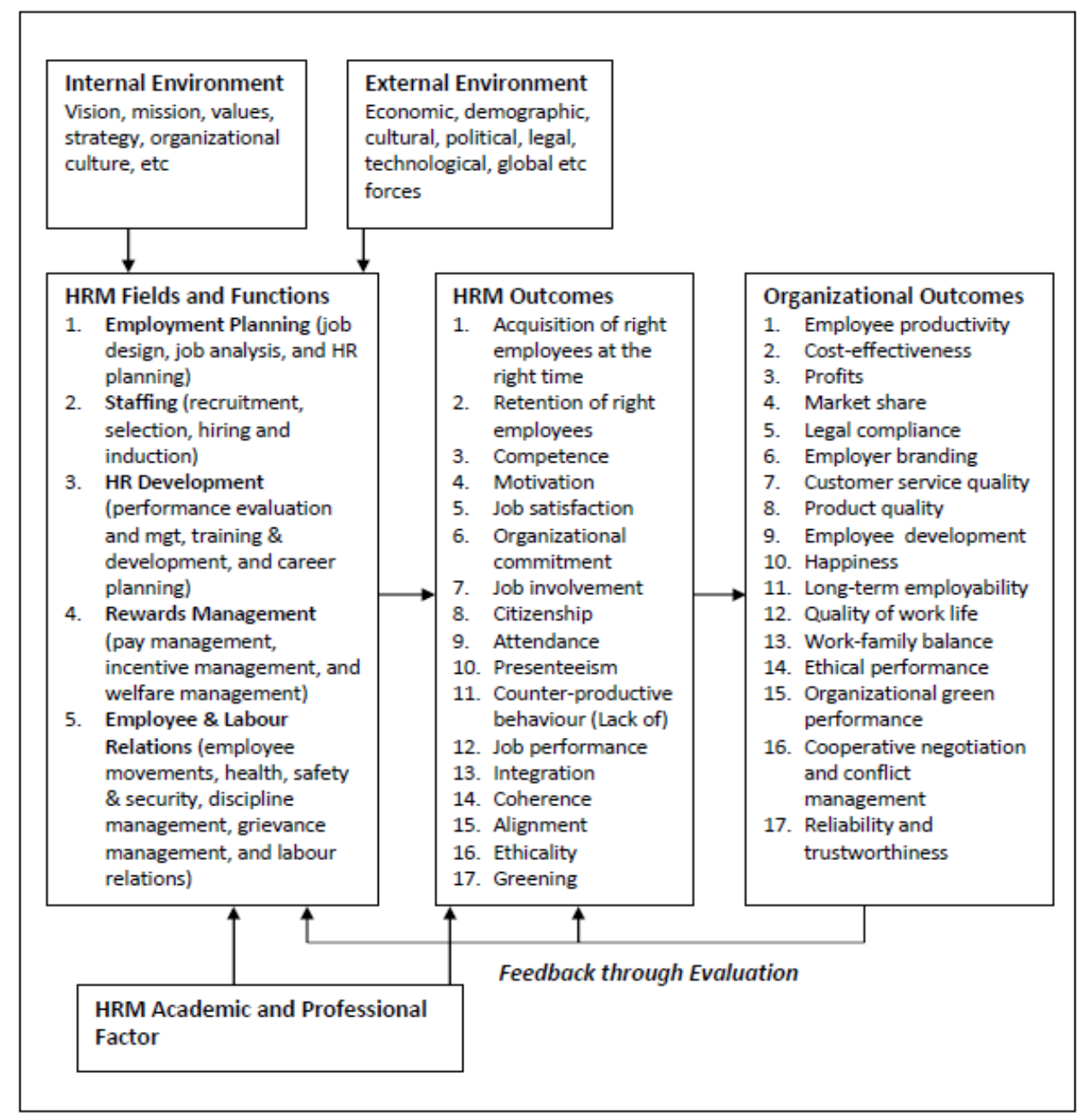

Figure 2. A Generic Model of HRM

HRM outcomes will result in organizational outcomes which represent organizational success. Organizational success may alternatively be called organizational effectiveness, business performance, or organizational performance (Ramawickrama, Opatha, \& Pushpakumari, 2017). One of the popular theories in management is Stakeholder Theory or Approach (Freeman \& McVea, 2001; Greenwood \& Simmons, 2004). If a question "For whom is HRM?" is asked, the answer needs to be ideally "for all stakeholders". Stakeholders are the parties or individuals who can affect and are affected by the performance of the organization. Primary stakeholders of an organization are owners (who have invested their money to start the organization), customers (who purchase the products of the organization to meet their various needs), employees (who give their competencies, time, effort etc to perform various jobs of the organization), other organizations such as suppliers (who provide various 
inputs needed by the organization to transform to produce goods or services) and unions (that have organized labour to protect relevant job or occupational interests), and society (people in general and the natural environment). The natural environment can be considered as a separate unique constituent as it is the planet. The natural environment includes lands, forests, plants, animals, and other natural phenomena; and people and organizations utilize various inputs from it as resources and therefore, they depend on the planet (Opatha, $2019^{3}$ ). Jackson \& Schuler (2003, p.17) write:

"The principle that effective management requires attending to all relevant stakeholders is as true for managing human resources as for other management tasks. Human resources practices cannot be designed solely to meet the concerns of employees. Nor can they be designed by considering only their consequences for the bottom line. Organizations that are the most effective in managing people develop HR systems that meet the needs of all key stakeholders."

Is it possible to meet the needs of all key stakeholders simultaneously? This is an important question in this context. There are two opposing ways of looking at the role of stakeholder management, i.e., zero sum and symbiosis (Dess, Lumpkin, \& Fisner, 2008). Zero Sum is a perspective that looks at stakeholders as competing for the organization's resources which are indeed limited. Gain obtained by one stakeholder group will become a loss of another stakeholder group (Dess, et al, 2008). Examples: (1) if employees get higher pay, that will reduce profits for shareholders; (2) If the company gives a donation to a charity, that will take money for the organization reducing profits for owners (Opatha, 2019 ${ }^{3}$ ). Thus according to this perspective, there will be conflicting demands. Symbiosis is a perspective that looks at stakeholders as parties who depend on each other for their success and well-being. Each group needs other groups for its success and survival, and managers acknowledge the interdependence among employees, suppliers, customers, shareholders, and the community at large (Dess, et al, 2008). Each group must reduce its greed and selfishness so as to get mutual gain to a significant extent. Close relationship should exist among the groups (Opatha, 2019 ${ }^{3}$ ). According to this perspective, the organization can get mutual gain through stakeholder symbiosis. Thus, in order to develop this model of HRM, symbiosis perspective was adopted. According to a theory of HR Co-creation proposed by Hewett \& Shantz (2021), HR and stakeholders optimize value through collaborative efforts to innovate in the design and use of HR practices to satisfy needs of multiple stakeholders in better way.

As far as the proposed generic model is concerned, success can happen at two levels, i.e., HRM level and organization level. Success at HRM level is represented by HRM outcomes. Organizational outcomes do represent success at organizational level. Thus, organizational success is the extent to which the specific organizational outcomes have been realized. Jackson and Schuler (2003) define success as effectively serving the interests of key stakeholders.

17 specific organizational outcomes have been mentioned in the model and they relate to the interests and needs of primary stakeholders, i.e., owners \& investors, customers, employees, society (including the natural environment), and other organizations such as suppliers and trade unions. Specific outcomes from 1 to 6 relate to satisfaction of owners and investors. Specific outcomes numbered 7 and 8 relate to customer satisfaction. Four specific outcomes from 9 to 12 relate to employees. Specific outcomes numbered 13, 14, and 15 relate to the needs of the society (including the natural environment). The needs of other organizations are related by specific outcomes numbered 16 and 17. Indeed items 1 and 5 relate to employees too. It is asserted that HRM can serve all these stakeholders.

HRM functions get changed or shaped by forces which are in the internal environment and the external environment. According to Institutional Theory pressures emanate from the internal and external environments, and an organization as a social entity seeks approval for its performance in socially constructed environments (Jackson \& Schuler, 1995). Institutional theory suggests that external pressures shape organizational action, and regulatory and social pressures are critical (Arulrajah \& Opatha, 2016). One internal force is strategy which is what top managers of the organization expect to accomplish in the long run. If strategy of an organization that is in super market industry includes an expansion of business such as starting a new shop in a new location it has a direct impact on HR planning, recruitment, selection, hiring, induction, and training. A new group of employees will have to be estimated, recruited, selected, hired, and inducted. Also the new staff will have to be trained. One external force is competition. An organization may face intense competition in labour market. When a large number of organizations compete for certain human resources, a greater attention has to be given to retaining high performers within the organization through appropriate actions such as a new career development programme and a new job redesign programme. To give a detailed analysis of various forces both in internal environment and external environment is beyond the objectives of this paper. 
Feedback through evaluation is an integral component of the model of HRM. Degree of successful performance of each HRM function needs to be measured in order to determine how well and how far it has been carried out. Furthermore, degree of accomplishment of each of HRM outcomes needs to be measured. For betterment of HRM in the future it is essential to get right answers for questions such as (1) Have HRM functions been carried out in the planned way or not? (2) Can they be improved further? (3) If yes, how can they be improved? (4) Have HRM outcomes (goals in another way) been accomplished? and (5) To what extent have they been accomplished?

Hence, feedback through measurement becomes essential. After measuring, deviations can be known and then remedial actions can be taken to make things better. Many years ago, a classic author of HRM (then Personnel Management) namely William F. Glueck (1979) explained the importance of evaluating the personnel functions and he utilized a term, i.e., Personnel Audit for evaluation of the personnel function. One of the most important functions of HR professionals is to evaluate talent management and development techniques and identify opportunities for the purpose of effective management of human capital (King, 2016). It is appropriate to mention here several approaches of HRM evaluation which include HR Scorecard (Opatha, 2009; Dessler, 2018), HR Audits (Werther \& Davis, 1996), HR Surveys (Schmitt \& Klimoski, 1991), HR Experiments (Sekaran \& Bougie, 2016), HR Qualitative Studies (Bryman \& Bell, 2011), and HR Analytics (Bhattacharyya, 2017; Opatha, 2020).

In the model, there is a component namely HR academic and professional factor. In this particular contextual factor, there are university academics who do new significant contributions to the existing body of knowledge of HRM and professionals who deal with professional institutes of HRM. For example, when a new book that contains new concepts and principles to enhance certain phenomena in the organizations was published by a well-known appropriately and highly qualified academic, HR manager and his or her staff of the organization may decide to adopt and adept the ideas of the book in managing employees. Consequently, new HRM systems get commenced.

Thus, HRM is a vast management phenomenon and it has certain distinct functions (may be called activities) to be carried out by HR manager and other managers. Successful performance of these HR functions will lead to accomplishment of HRM outcomes. Then, the accomplishment of HRM outcomes results in organizational outcomes. Furthermore, these HRM functions are shaped by various forces in the internal environment and external environment. It is essential to do feedback through measurement for making successful performance of HRM functions better and increasing the degrees of accomplishment of HR outcomes. HRM academic and professional factor contributes to formulation, addition or dropping of certain HRM systems or practices.

An attempt was made to adapt the General System Theory to underpin the proposed generic model of HRM. According to Wright \& Snell (1991) the general system theory has a discussion of inputs, processes, and outputs. At this model, the inputs are various forces which exist in the internal environment and the external environment as well. HRM fields and functions are to be considered as processes. HRM outcomes and organizational outcomes become the outputs. For the purpose of developing an expanded underpinning, the Resource-based View of the Firm is adapted. According to Barney (1991), the resource-based view makes it clear that sustained competitive advantages can only be found in the rare, imperfectly imitable and non-substitutable resources which are present in the firm. Competitive advantage is only possible to happen in situations of firm resource heterogeneity and firm resource immobility (Wright \& McMahan, 1992). The resource-based view of the firm is a perspective that firms' competitive advantages are due to their endowment of strategic resources that are valuable, rare, costly to imitate, and costly to substitute (Dess, et al, 2008). Through sound performance of HRM functions it is possible for the organization to acquire, develop, and maintain employees who are valuable, rare, difficult to imitate, and difficult to substitute. These unique employees enable the organization to realize various HRM outcomes and organizational outcomes.

HRM literature (Hendry, \& Pettigrew, 1986; Schuler, 1992; Kleiman, 2000; Mello, 2002; Anthony, Kacmar, \& Perrewe, 2010; Stewart \& Brown, 2014) provides a useful perspective called Strategic Perspective. The strategic perspective mainly focuses on (1) utilizing human resources and HRM as a source of sustainable competitive advantage (Kleiman, 2000; Mello, 2002); (2) HRM is integrated with the strategy and strategic needs of the organization such as vision, mission, and goals (Anthony et al, 2006); (3) HRM policies and functions cohere within themselves and with other functional fields of the organization (Opatha, 2009); and (4) HRM strategies are aligned with competitive business strategies (Stewart \& Brown, 2009). Certain HRM outcomes such as integration, alignment, and coherence come from the strategic perspective.

Finally, another perspective called Sustainability Perspective is considered as a significant underpinning for the 
generic model of HRM proposed by me. Sustainability perspective drives from the paradigm of Triple Bottom Line introduced by Elkington (1994, as in Johnson, 2007), framework of Sustainable HRM introduced by De Prins in 2011 (as in Rompa, 2011), the writing by Cohen, Taylor, \& Muller-Camen (2012), and the writing by Kramar (2013). Greening which derives from sustainability perspective is a critical employee requirement to be created and enhanced within every employee in every organization (Opatha, 2013; Opatha \& Arulrajah, 2014; Opatha and Kottawatta, 2020). Opatha $\left(2019^{3}\right.$, p. 31) defines: "Sustainable HRM is that part of HRM which is concerned with Planet-related matters, Society-related matters and Profit-related matters. It refers to the policies, procedures, rules, practices, and systems of managing employees which contribute to achieve sustainability." As a result of this perspective, I included presenteeism (Werapitiya, Opatha, \& Fernando, 2016), ethicality (Silva, Opatha, \& Gamage, 2016), and greening as HRM outcomes; and profits, employer branding, happiness, work-family balance, ethical performance, and organizational green performance as organizational outcomes.

\section{Conclusion}

I decided not to use certain generally accepted research methods for this research paper as it is a non-scientific one, but an original theoretical research paper. Being a basic or pure paper, this paper was written to achieve three research objectives. The first one was: "To perform a brief description of selected popular models of HRM developed by various scholars or authors". 34 textbooks and 07 scholar books which were readily available to me were examined and five models were selected owing to their international popularity and personal interest. The Matching Model by Devanna, Fombrun \& Tichy; the Harvard Model of HRM by Beer, Spector, Lawrence, Mills, \& Walton; the Model of HRM by David Guest; the Framework for Managing Human Resources through Strategic Partnerships by Jackson \& Schuler; and the ARDM Model of HRM by Ivancevich were described.

The second research objective of this paper was: "To revisit and review the model of HRM developed by me in 2009". This model consists of 18 functions of HRM, objectives of HRM, strategic goals of HRM, and the generic purpose of HRM. The model shows the sequential order and the network of relationships among the components. Finally, a brief review was performed and it was argued that the model is an internally focused model as it does not include environmental aspects, both external and internal. However, it is indeed useful and valid.

The third research objective was: "To introduce a generic model of HRM with an adequate theoretical base". A generic model of HRM was developed and presented in a simplified and lucid way and it is composed of seven components with a logical network of relationships. The seven components include internal environment, external environment, HRM fields and functions, HRM outcomes, organizational outcomes, HRM academic and professional factor, and feedback through evaluation. 17 HRM outcomes were specified and 17 organizational outcomes were specified. Common theories and perspectives such as stakeholder theory, symbiosis, general system theory, the resource-based view of the firm, institutional theory, strategic perspective, and sustainable perspective were used to provide a sufficient underpinning to the generic model of HRM developed in this paper. In addition, arguments and empirical observations given and made by other scholars were utilized. In fact, logical beliefs of the author of this paper were instrumental in developing the model. It is expected that the model of HRM developed in this paper gives a significant original contribution to the existing body of knowledge of HRM, not only the local knowledge but the global knowledge too. To perform empirical studies based on the model is indeed useful for providing empirical evidence and substantiation. Correlational studies and field experiments by using a set of variables deriving from the model are suggested generally.

\section{References}

Anthony, W. P., Kacmar, K. M., \& Perrewe, P. L. (2010). Human Resource Management: A Strategic Approach. Mason: Cengage Learning.

Arulrajah, A. A., \& Opatha, H. H. D. N. P. (2016). Analytical and Theoretical Perspectives on Green Human Resource Management: A Simplified Understanding. International Business Research, 9(12), 153-164. https://doi.org/10.5539/ibr.v9n12p153

Barney, J. (1991). Firm resources and sustained competitive advantage. Journal of Management, 17(1), 99-120. https://doi.org/10.1177\%2F014920639101700108

Beardwell, J., \& Claydon, T. (2007). Human Resource Management: A Contemporary Approach (5th ed.). London: Prentice-Hall.

Bhattacharyya, D. K. (2017). HR Analytics. SAGE Texts.

Bryman, A., \& Bell, E. (2011). Business Research Methods (3rd ed.) OXFORD University Press. 
Cohen, E., Taylor, S., \& Muller-Camen, M. (2012). HRM's Role in Corporate Social and Environmental Sustainability. Society for HRM (SHRM) Foundation.

Davis, D., \& Cosenza, R. M. (1985). Business Research Methods. Boston: PWS-KENT Publishing Company.

Dess, G. G., Lumpkin, G. T., \& Eisner, A. B. (2008). Strategic Management. Boston: McGraw-Hill Irwin.

Dessler, G. (2018). Human Resource Management (15th ed.) Boston: Pearson.

Devanna, M. A, Fombrun, J., \& Tichy, N. M. (1984). A Framework for Strategic Human Resource Management. In Fombrun, J., Tichy, N. M., \& Devanna, M. A. (1984), Strategic Human Resource Management. New York: John Wiley and Sons.

Devanna, M. A., Fombrun, C. J., \& Tichy, N. M. (1984). A Framework for Strategic Human Resource Management. In Fombrun, C. J., Tichy, N. M., \& Devanna, M. A. (Ed.), Strategic Human Resource Management. New York: John Wiley and Sons.

Freeman, R. E., \& McVea, J., (2001). A Stakeholder Approach to Strategic Management. In Hitt, M., Freeman, E., \& Harrison, E. (Ed.), Handbook of Strategic Management. Oxford: Blackwell Publishing. https://doi.org/10.2139/ssrn.263511

Glueck, W. F. (1979). Foundations of Personnel. Texas: Business Publications Inc.

Greenwood, M. R., \& Simmons, J. (2004). A stakeholder approach to ethical human resource Management. Business \& Professional Ethics Journal, 23(3), 3-23. https://doi.org/10.5840/bpej200423313

Guest, D. (1987). Human Resource Management and Industrial Relations. Journal of Management Studies, 24(5), 503-5221. https://doi.org/10.1111/j.1467-6486.1987.tb00460.x

Hendry, C., \& Pettigrew, A. (1986). The Practice of Strategic HRM. Personnel Review, 15(5), 3-8. https://doi.org/10.1108/eb055547

Hewett, R., \& Shantz, A. (2021). A Theory of HR Co-creation. Human Resource Management Review. https://doi.org/10.1016/j.hrmr.2021.100823

Ivancevich, J. M. (2010). Human Resource Management. Boston: McGraw-Hill Irwin.

Jackson, S. E., \& Schuler, R. (1995). Understanding Human Resource Management in the Context of Organizations and Their Environments. Annual Review of Psychology, 46(1), 237-264. https://doi.org/10.1146/annurev.ps.46.020195.001321

Jackson, S. E., \& Schuler, R. (2003). Managing Human Resources Through Strategic Partnership. $8^{\text {th }}$ edi, Ohio: Thomson, South-Western.

Johnston, A. (2007). HIGHER EDUCATION FOR SUSTAINABLE DEVELOPMENT. Final Report of International Action Research Project, the Organization for Economic Co-operation and Development (OECD).

Kleiman, L. S. (2000). Human Resource Management: A Managerial Tool for Competitive Advantage. Cincinnati, Ohio: Atomic Dog Publishing.

Kramar, R. (2013). Beyond strategic human resource management: is sustainable human resource management the next approach?. The International Journal of Human Resource Management, 25(8), 1069-1089. https://doi.org/10.1080/09585192.2013.816863

Legge, K. (1995). Human Resource Management: Rhetorics and Realities. London: Macmillan Business. https://doi.org/10.1007/978-1-349-24156-9

Mello, J. A. (2002). Strategic Human Resource Management. Ohio: South-Western College Publishing.

Nazario-Romero, M. (2016). Definitions and Types of Research Articles. The Veteran Spouse Network, June 21. Retrieved from https://www.texvet.org/sites/default/files/VSN_White_Paper_Types_Research_\%20Articles.pdf

Opatha, H. H. D. N. P. (1995). Sewamandala Kalamanakaranaya (Personnel Management). Colombo: Author Publication.

Opatha, H. H. D. N. P. (2009). Human Resource Management: Personnel. Colombo: Department of HRM, University of Sri Jayewardenepura. https://doi.org/10.31357/bkc.fmsc.00001

Opatha, H. H. D. N. P. (2013). Green Human Resource Management: A Simplified Introduction. HR Dialogue, Department of HRM, Faculty of Management Studies and Commerce, University of Sri Jayewardenepura, 
$22-41$.

Opatha, H. H. D. N. P. (2019 $)$. A Study of Bachelor's Degrees in Human Resource Management in Three Sri Lankan Leading State Universities. Universal Journal of Educational Research, 7(11), 2361-2371. https://doi.org/10.13189/ujer.2019.071114

Opatha, H. H. D. N. P. $\left(2019^{2}\right)$. The Case for Teaching Human Resource Management in Management Education: 13 Common Reasons. Sri Lankan Journal of Human Resource Management, 9(2), 15-38. https://doi.org/10.4038/sljhrm.v9i2.5653

Opatha, H. H. D. N. P. $\left(2019^{3}\right)$. Sustainable Human Resource Management: Expanding Horizons of HRM. Colombo: Department of HRM, University of Sri Jayewardenepura.

Opatha, H. H. D. N. P. (2020). Influence of Lecturers' Competence on Students' Satisfaction of Lecturing: Evidence for Mediating Role of Lecturing Behaviour. Universal Journal of Educational Research, 8(4), 1167-1179. https://doi.org/10.13189/ujer.2020.080406

Opatha, H. H. D. N. P., \& Anton Arulrajah, A. (2014). Green Human Resource Management: Simplified General Reflections. International Business Research, 7(8), 101-112. https://doi.org/10.5539/ibr.v7n8p101

Opatha, H. H. D. P. J. (2020). HR Analytics: A Literature Review and New Conceptual Model. International Journal of Scientific and Research Publications, 10(6), 130-141. https://doi.org/10.29322/IJSRP.10.06.2020.p10217

Opatha, H. H. D. P. J. \& Kottawatta, H. (2020). Green HRM and Environmental (Green) Attitude: Do Green HRM Practices of Sri Lankan Tiles Industry Affect to Determine the Environmental (Green) Attitudes of the Employees? International Journal of Management Excellence, 15(2), 2207-2219.

Ramawickrama, J., Opatha, H. H. D. N. P., \& Pushpakumari, M.D. (2017). A Synthesis towards the Construct of Job Performance. International Business Research, 10(10), 66-81. https://doi.org/10.5539/ibr.v10n10p66

Rompa, I. (2011). Explorative Research on Sustainable Human Resource Management. Master's Thesis, VU University Amsterdam.

Schmitt, N. W., \& Klimoski, R. J. (1991). Research Methods in Human Resources Management. Cincinnati: South-Western Publishing Co.

Schuler, R. (1992). Strategic Human Resource Management: Linking the People with the Strategic Needs of the Business. Organizational Dynamics, 21(1), 18-32. https://doi.org/10.1016/0090-2616(92)90083-Y

Sekaran, U., \& Bougie, R. (2016). Research Methods for Business: A Skill Building Approach (6th ed). WILEY.

Silva, N. G. V. A., Opatha, H. H. D. N. P., \& Gamage, A. S. (2016). Towards Extending the Ethical Dimension of Human Resource Management. International Business Research, 9(10), 152-161. https://doi.org/10.5539/ibr.v9n10p151

Stewart, G. L., \& Brown, K. G. (2014). Human Resource Management: Linking Strategy to Practice (3rd ed.). Hoboken, NJ: John Wiley \& Sons, Inc.

Vickerstaff, S. (1992). Human Resource Management in Europe: Text and Cases. London: CHAPMAN \& HALL.

Werapitiya, C., Opatha, H. H. D. N. P., \& Fernando, R. L. S. (2016). Presenteeism: ItsImportance, Conceptual Clarifications, and A Working Definition. International Journal of Scientific \& Engineering Research, 7(2), 1489-1506. https://doi.org/10.2139/ssrn.2699782

Werther, B. W., \& Davis, K. (1996). Human Resources and Personnel Management (4nd ed). New York: McGraw- Hill Book Company.

Wright, P. M., \& McMahan, G. C. (1992). Theoretical Perspectives for Strategic Human Resource Management. Journal of Management, 18(3), 295-320. https://doi.org/10.1177/014920639201800205

Wright, P. M., \& Snell, S. A. (1991). Towards an integrative view of strategic human resource management. Human Resource Management Review, 1(3), 203-225. https://doi.org/10.1016/1053-4822(91)90015-5

\section{Copyrights}

Copyright for this article is retained by the author(s), with first publication rights granted to the journal.

This is an open-access article distributed under the terms and conditions of the Creative Commons Attribution license (http://creativecommons.org/licenses/by/4.0/). 